\title{
Indicators of financial distress condition in Indonesian banking industry
}

\author{
Abdul Haris ${ }^{\text {a }}$ Imam Ghozali ${ }^{\text {** }}$ and Najmudin ${ }^{\text {a }}$
}

${ }^{\mathrm{a}}$ Lecturer at Faculty of Economics and Business, Universitas Jenderal Soedirman, Indonesia

${ }^{b}$ Professor in Accounting at The Faculty of Economics and Business, Diponegoro University Indonesia

\section{H R O N I C L E}

\begin{tabular}{l}
\hline Article history: \\
Received March 10, 2021 \\
Received in revised format May \\
102021 \\
Accepted June 102021 \\
Available online \\
June 102021 \\
\hline Keywords: \\
Financial distress \\
Banking sector in Indonesia \\
Credit risk \\
Profitability \\
Liquidity
\end{tabular}

\section{Introduction}

During the pandemic, the Covid 19 outbreak has been becoming a global issue and had a devastating impact on the global economy. During the Covid 19 pandemic, which has been sticking out since early 2019, it has imposed new policies, especially the economic policies. The banking sector, which is the driving force for the economy, both nationally and internationally, has a very important role in restoring the global economic downturn into better economic condition. Most of the economic sectors, especially the financial, require banking services. During the Covid 19 pandemic, most countries throughout the world had been affected by economic downturns caused by the policy of Limitation of large-scale economic activity, some countries even implemented 'Lock down' policies. The banking sector is one of the economic sectors that has been adversely impacted on decreasing income, since Non-performing Loan problems and issue of restrictions on international transactions are increased, which have generated financial distress in the banking sector, as well as in Indonesian banking sector. The issue of financial distress that occurs in banking is one of the risks that can appear and need to be recovered. One of the most visible risks and considered to be the main cause of bank default is a credit risk (Vassalou \& Xing, 2004), therefore credit creation program is an activity to generate main income of the bank (Kargi, 2011). Credit risk is the main factor affecting the financial distress and if credit risk is continuously improved, it will derive financial distress, even leading to bankruptcy. Predicting the financial distress is the aim of knowing earlier prior to the bankruptcy * Corresponding author

E-mail address: imam.ghozali@live.undip.ac.id (I. Ghozali) 
stage, besides the credit risk as the main factor, there are other factors that can affect financial distress conditions in the banking sector, they are including; capital, decreasing profits, the amount of third party funds allocated channeled for loans and management. These factors in many studies are used to measure financial distress and bankruptcy in the banking sector by using the term of CAMEL, namely Capital, Asset Quality, Management, Earning, Liquidity. Over the past two decades, many organizations in all sectors of the economy have received financial difficulties, so it is required to identify models that can assist investors evaluating corporate finances (Ashraf et al., 2019). The same condition also is raised in Indonesia where several banks and non-bank financial institutions are affected by financial difficulties and even bankruptcy, so that for assisting investors in assessing and evaluating the current and future financial condition of companies, it is necessary formulate a viable predictive model of financial distress and bankruptcy.

There are literally many studies associated with financial distress, including Brownbridge (1998) Altman (2002), Plat and Plat (2002), Rahman et al. (2004), Zaki et al. (2011). Research on the financial distress still has come to attention from researchers among academics, including Lee and Mullineaux (2014), Keffala et al. (2018), Gadzo et al. (2019), Ledhem and Mekidiche (2020). The studies were conducted as an early warning measure for financial distress. Research on prediction of financial distress affected by credit risk factors conducted by some researchers declared different results among them, some have a positive effect, and some have a negative effect. Researchers who declared the positive effects and some declared a negative effect (Muriithi et al., 2016). Moreover, some other studies reported contradicting results. Other than credit risk, there are several other factors that create financial distress, namely Capital Adequacy (Capital), Profitability (Earning), Liquidity (Liquidity). These factors are commonly used to predict financial distress with the CAMEL framework in banking sectors in several countries. Several studies that predict financial distress in the banking sector with the CAMEL framework are Rahman et al. (2004), Keffala et al. (2017), Gutiérrez-López and Abad-González (2020. Research on financial distress prediction using the CAMEL framework by Indonesian researchers includes Kurniasari and Ghozali (2013), Kuncoro and Agustina (2017), Yurivin and Mawardi (2018), etc. The purpose of this study is to determine and analyze the impact of variables Capital, Credit Risk, Profitability and Liquidity on Financial Distress by sampling conventional commercial banks in Indonesia within the period of 2015-2019. Various variables that have potentially strong implications to Financial Distress conditions include Capital, Credit Risk (Assets Quality), Management, Profitability (Earning), and Liquidity. The scope of this study will be limited to variables Capital proxied by a Capital Adequacy Ratio (CAR), Profitability proxied by Return on Assets (ROA), Liquidity proxied by the Loan to Deposit Ratio (LDR) that those are able to encourage Financial Distress condition.

\section{Literature review and hypothesis development}

\subsection{Financial Distress}

Fitzpatrick (1932) was one of the first ones who defined financial distress. According to his study, financial distress is defined as a company's inability to meet its current financial obligation to creditors. Financial distress can manifest in various forms, depending on the type of event that occurred such as bankruptcy, unclosed bonds, bank overdrafts or unpaid priority shares dividend (Beaver 1966). Other definitions of financial distress; Plat and Plat (2002) define financial distress as a late stage of corporate decline in financial conditions that precede more cataclysmic event such as bankruptcy stage, then Brigham and Daves (2003) financial distress begins when the company cannot meet the payment schedule or when cash flow projections indicate that the company will soon to be unable to meet its obligations. Others define that financial distress is a condition of liquidity difficulty that precedes bankruptcy. The banking sector is strongly required to take its role as a driving force of the economy, so that in case of financial distress it will disrupt the economy and derive a negative impact on the economic sector. Banks in financial stress condition and even on verge of bankruptcy will disrupt payment system activities and will disrupt the distribution of credit loans to local communities (Gilbert and Meyer, 1991). Researchers who still pay attention to financial stress, including Keffala (2018), Gadzo et al. (2019), Ledhem and Mekidiche (2020), Onsongo et al. (2020).

\subsection{Capital}

Capital is concrete goods that are still in the company's household stated on the debit balance as well as value of the purchasing power or exchange rate of goods listed on the credit balance. Meanwhile, the definition of capital could be defined as a kind of loan within a certain period of time owned by a company, or all the accounts contained in the righthand column of the company balance sheet statement other than the current obligations. Capital based on the sources can be divided into internal capital that comes from internal sources within the company and external capital that sourced from outside of the company. The role level of capital is a buffer against losses caused by non-performing loans or defaulted loans. Adequacy of Capital can reduce losses and risks. In addition, Capital can shore up bank financing and operations, provide protection to depositors and other creditors, and inspire trust among depositors and regulators. (Rahman et. Al, 2004). It can be concluded that credit loan default will reduce capital adequacy, this will result bank CAR to decline, and low CAR indicates the bank is unhealthy. An unhealthy condition will impose the bank to reserve more liquidity to increase capital adequacy. The higher level of capital secured by the bank; it will be much stronger to cover risks of loss. Several 
studies support the results that CAR has a positive effect on Financial Distress. Based on the above description, the hypothesis can be formulated as follows:

\section{$\mathbf{H}_{1}$ : Capital has a positive effect on Financial Distress.}

\subsection{Credit Risk}

The main cause of bank failure and the most visible risk faced by banks is credit risk (Gup et al., 2007; Ashraf et al., 2019). NPL is a credit risk, much higher level of the NPL, much higher the cost of the Provision for Loan Losses (PPAP) which is a cost and will obviously reduce profits (Rahman et.al). In the banking sector, credit risk management is an important part of risk management, so it must be controlled properly and effectively for long-term survival (Zribi \& Boujelbene (2011). Several previous studies on the effect of credit support the result that credit risk has a positive effect on financial distress conditions, such as Isanzu (2017). Based on the above description, the hypothesis can be formulated as follows:

\section{$\mathbf{H}_{2}$ : Credit risk has a positive effect on Financial Distress.}

\subsection{Profitability}

Profitability is the bank's ability to generate profits. Profitability is proxied by Return on Assets (ROA). More profit can be generated, more retained earnings can be served to strengthen the capital and far more resilient in covering risks. Several studies support the results that profitability has a positive effect on Financial Distress (Kablay \& Gumbo, 2020). Based on the above description, the hypothesis can be formulated as follows:

\section{H3: Profit (earnings) has a positive effect on Financial Distress.}

\subsection{Liquidity}

Liquidity that is proxied by the Loan To Deposit Ratio (LDR) which is how much credit is distributed to third party funds, so the LDR calculation is the ratio between loans disbursed and third party funds. The higher the ratio indicates the lower level of liquidity of the bank. Several studies support the result that Liquidity has positive effect on financial distress (Keffala, 2018). Based on the descriptions, the hypothesis can be formulated as follows:

\section{$\mathbf{H}_{4}$ : Liquidity has a positive effect on financial distress.}

From the explanation of the above hypothesis, the following research model is obtained:

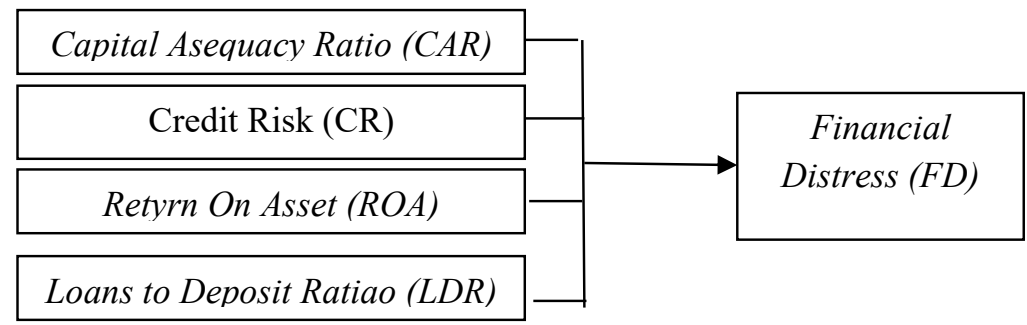

Fig. 1. Reserach Model

\section{Method of study}

\subsection{Types of research}

This research is an associative research as the aim is for analyzing and knowing the correlation between two or more variables (Sugiyono, 2017: 37). This study will examine the theory or hypothesis with statistical approach by measuring linearly and explaining the causal correlation between variables, where the formulated hypothesis will result in a statement whether it is 'accepted' or 'rejected.

\subsection{Population and Sample}

The population in this study are all conventional commercial banks in Indonesia registered in the Financial Services Authority of Indonesia within the period 2015-2019. The population in this study included 146 observations. From the total 
number of populations, sampling will be selected among the populations. Determination of the sample in this study using a non-probability sampling method, namely purposive sampling which is a method of determining samples with certain considerations (Sugiyono, 2017: 120). The criteria specifically in this study are: (1) conventional commercial banks registered in the Financial Services Authority of Indonesia within the period of 2015-2019, (2) Banks that being in Earning decline within the period of 2015-2019, (3) Commercial banks that release the completed annual financial reports to public within the period of 2015-2019, (4) the bank that can be easily accessed to obtain entire variables data for this research purposes within the period of 2015-2019.

\subsection{Data collection technique}

Data collection technique with Literature and documentation reviews. Literature review was carried out by searching for relevant references, studying books, journals, articles and the results of study from the researchers that are relevant to the scope of this study. Documentation was carried out by collecting secondary data such as time series of published annual reports of national conventional commercial banks within the period of 2015-20119, then data processing.

\subsection{Variables of Research}

In this study, five variables of research were included to assess, one dependent variable and four independent variables. The dependent variable in this study is Financial Distress, while the independent variables are Capital Adequacy Ratio (CAR), Credit Risk (CR), Return On Assets (ROA), Loans to Deposit Ratio (LDR).

Financial Distress (FD)

Financial distress can be assessed by the formula or equation of the Modified Zscore Model, Altman Zscore (1995), which is a model for non-producers and for developing country markets.

$Z=6.56(X 1)+3.26\left(X_{2}\right)+6.72\left(X_{3}\right)+1.05(X 4)$

where

$$
\begin{aligned}
& \mathrm{X}_{1}=\text { Working Capital / total assets, } \\
& \mathrm{X}_{2}=\text { Retained Earning / total assets, } \\
& \mathrm{X}_{3}=\text { Earning before interest and taxe / total assets, } \\
& \mathrm{X}_{4}=\text { Equity market value / Book value of Debt }
\end{aligned}
$$

Capital Adequacy Ratio (CAR), calculated by the following formula:

$$
C A R=\frac{\text { Capital }}{\text { Risk Weighted Asset }(R W A)}
$$

Credit Risk (CR), calculted by the following formula:

$$
\text { Re Adjusted Return On Capital (RAROC) }=\frac{\text { Return }}{\text { Risk Weighted Asset (RWA) }}
$$

Return On Asset (ROA), calculted by the following formula:

$$
\text { Return On Asset }(\text { ROA })==\frac{\text { Net Income (EAT) }}{\text { Total Asset }}
$$

Loans to Deposit Ratio (LDR), calculted by the following formula:

$$
L D R=\frac{\text { Loan }}{\text { Total third party fund (Deposit) }}
$$

\subsection{Data analysis technique}

\section{Data Analysis Method}

Data analysis was performed with Multiple Regression Analysis using the SPSS program (Ghozali, 2013), which consists of: 


\section{Classic Assumption Test}

The collected data is tabulated and then the classical assumption test will be carried out as a prerequisite for regression analysis as follows:

\section{a. Normality test}

To find out whether the residuals studied were normally distributed or not, a normality test was performed. By using the Kolmogorov Smirnov method. The standardized residual value curve is said to spread normally if the Kolmogorov Smirnov $\mathrm{Z}<\mathrm{Z}$ table or the Asymp value. $\quad$ Sig. (2-tailed) $>\alpha$.

b. Multicollinearity Test

To determine the presence or absence of multicollinearity between variables, a multicollinearity test was performed. If the regression equation contains multicollinearity symptoms, it means there is a correlation (near perfect) between the independent variables. If the Variance Inflation Factor (VIF) value is not more than 10, this indicates that there is no multicollinearity symptom, meaning that there is no relationship between the independent variables. In addition, that using the VIF value, it can also find out the value of the correlation coefficient between the independent variables, if not less than 0.5 , the model does not contain elements of multicollinearity.

\section{c. Heteroscedasticity Test}

To determine the variance of variables in the model that are not the same (constant), a heteroscedasticity test was performed. To detect the presence or absence of heteroscedasticity symptoms in this study, the Glejser method is then to be used. The symptom of heteroscedasticity is indicated by the regression coefficient of each independent variable on the absolute value of the residue (e), if the probability value $>$ alpha value $(0.05)$, then the model does not contain elements of Heteroscedasticity.

\section{d. Autocorrelation Test}

The autocorrelation test is a statistical analysis conducted to determine whether there is a correlation between the variables in the prediction model and changes in time. Therefore, if the assumption of autocorrelation used in a prediction model, the disturbance value is no longer paired independently, but is paired in autocorrelation.

\section{Multiple Regression Analysis}

\section{Regression equation/formula}

Multiple regression can be used to examine correlation between dependent variables and four independent variables. The correlation which is formulated to test the truth of hypothesis statements of the research. In general the multiple regression formula is as follows:

$$
\mathrm{Y}=\mathrm{a}+\mathrm{b} 1 \mathrm{X} 1+\mathrm{b} 2 \mathrm{X} 2+\mathrm{b} 3 \mathrm{X} 3 \ldots .+\mathrm{bnXn}+\mathrm{e}
$$

\section{Results and discussion}

\subsection{Descriptive Statistical Analysis}

This research was conducted on the conventional banking sector in Indonesia. The variables examined in this study consist of Capital, Credit risk, Profitability, and Liquidity as independent variables and Financial Distress as the dependent variable. The results of descriptive statistics for these variables are presented in Table 1.

Table 1

Descriptive Statistic

\begin{tabular}{lccccc}
\multicolumn{1}{c}{ Variable } & $\mathrm{N}$ & Min & Max & Mean & Std. Deviation \\
\hline Capita (CAR) & 146 & 11.62 & 51.28 & 22.4537 & 6.2306 \\
Credit risk (RAROC) & 146 & 0.00 & 0.06 & 0.0247 & 0.0134 \\
Profitability (ROA) & 146 & 0.15 & 4.24 & 2.0508 & 0.9800 \\
Liquidity (LDR) & 146 & 55.35 & 128.08 & 91.2681 & 12.9677 \\
Financial Distress (Z Score) & 146 & 0.51 & 3.13 & 1.5231 & 0.5085 \\
\hline
\end{tabular}

Based on Table 1, it is shown that the average capital value as proxied by the capital adequacy ratio (CAR) of conventional commercial banks in Indonesia in the period of 2015-2019 was 22.45 percent. According to Bank of Indonesia Regulation No. 15 of 2013 concerning the Minimum Capital Requirement for Commercial Banks, the minimum CAR that must be reached by commercial banks is 8 percent. While the data indicated that conventional commercial banks in Indonesia were still in sufficient capital adequacy since their average CAR was far above the recommended value. Based on Table 1, it is 
known that the average value of credit risk as proxied by the risk adjusted return on capital (RAROC) of conventional commercial banks in Indonesia in the period of 2015-2019 was 2.47 percent. Much lowering the RAROC value will indicate much higher credit risk for the bank. A low RAROC means that the percentage of profits derived from risk-weighted assets is also at a low level.

Based on Table 1, it is shown that the average value of the profitability variable which is proxied by return on assets in conventional banking in the period of 2015 to 2019 was 2.05 percent. The data illustrated that the average profitability was in a fairly good condition since the banks were able to generate positive returns. The average value of the liquidity variable as proxied by the loan to deposit ratio (LDR) in conventional commercial banking sector in the period of 2015 to 2019 was 91.26 percent. The data indicated that in general the conventional banking sector in Indonesia reached a fairly good level of liquidity, or in other words, credit loans were effectively distributed. The average value of the Financial Distress variable, which is proxied by the Altman Z-Score, was 1.52. These data indicate that conventional commercial banks in Indonesia, despite reaching good level of profitability, the possibility of Financial Distress could remain, due to inconsistencies and fluctuations in Earning.

\subsection{Classic Assumption Test}

The right regression model is one that meets the BLUE (Best Linear Unbiased Estimator) principle. Several prerequisite tests were carried out to obtain a good model, namely normality, multicollinearity and heteroscedasticity tests.

\section{a. Normality test}

The normality of data in a regression model is an important thing to get a good model or a model that meets the BLUE (Best Linear Un] Estimator) principle. The normality test was carried out on the residual value. The residual value is obtained from the differences between the actual $\mathrm{Y}$ value and the predicted $\mathrm{Y}$ value. Testing for normality used the Kolmogorov Smirnov method. Determine whether the residual data has a normal distribution or not by looking at the asymp sig value. on the output of the Kolmogorov Smirnov analysis. The asymp sig. value when it is greater than 0.05 , will prove that residual value is normally distributed. A summary result of the normality test can be presented in Table 2.

Table 2

Normality Test Result

\begin{tabular}{lll}
\hline $\mathrm{N}$ & & Unstandardized Residual \\
Normal Parameters & & 146 \\
& Mean & .0000000 \\
Most Extreme Differences & Std. Deviation & .22974945 \\
& Absolute & .068 \\
& Positive & .064 \\
Statistical Test & Negative & -.068 \\
\hline Asymp. Sig. (2-tailed) & & 0.068 \\
\hline
\end{tabular}

As shown in Table 2, The asymp si. value obtained from the analysis was 0.100 , and due to the value being greater than 0.05 the residual value in this study was assumed to be a normal distribution.

\section{b. Multicollinearity Test}

Multicollinearity testing can detect whether there is a very significant or perfect correlation among the independent variables in the research model. A model that can meet the BLUE principle expects the model does not have a perfect correlation among independent variables. The Variance Inflation Factor (VIF) method was used to test multicollinearity. The conclusion is whether there was a multicollinearity by assessing the VIF value for each independent variable. A VIF value less than 10 indicates no multicollinearity in the model. The multicollinearity test results can be presented in Table 3 .

Table 3

Multicollinearity Test Result

\begin{tabular}{lll}
\hline Variable & Tolerance & VIF \\
\hline Capital (CAR) & 0.841 & 1.189 \\
Credit Risk (RAROC) & 0.863 & 1.159 \\
Profitability (ROA) & 0.907 & 1.103 \\
Liquidity (LDR) & 0.940 & 1.064 \\
\hline
\end{tabular}


Table 3 showed the VIF value for the variable Capital, Credit risk, Profitability Liquidity, and their were all value is respectively below 10, so the conclusion was that there was no multicollinearity in the research model.

\section{c. Heteroscedasticity Test}

Heteroscedasticity means that the residuals in the model from one observation to another are not constant, while the conditions that are expected creating the right model that are homoscedastic or the observations from one observation to another are constant. The Gleyser method is used to detect the presence or absence of heteroscedasticity in the model. The conclusion whether there is heteroscedasticity in the model by looking at the significance value of each independent variable. The acceptable value is that a significance value should be greater than 0.05 . The results of the heteroscedasticity test can be presented in Table 4 .

\section{Table 4}

Heteroscedasticity Test Result

\begin{tabular}{ll}
\hline Variable & Sig. \\
\hline Ln_Capita (CAR) & 0.471 \\
Ln_Credit Risk (RAROC) & 0.326 \\
Ln_Profitability (ROA)^2 & 0.104 \\
Ln_Liquidity (LDR) & 0.103 \\
\hline
\end{tabular}

As shown in Table 4, the significance values for variables Capital, Credit risk, Profitability, and Liquidity were all respectively greater than 0.05 , which means that the residuals were constant or homoscedasticity.

\section{Multiple Regression Analysis}

\section{a. Regression equation}

Table 5 shows the output from the result of multiple regression analysis. The results of the analysis were aimed to form the regression equation and test the hypothesis.

Table 5

Multiple Regression Analysis Result

\begin{tabular}{|c|c|c|c|c|}
\hline \multirow{2}{*}{ Variables } & \multicolumn{2}{|c|}{ Unstandardized Coefficients } & \multirow{2}{*}{$\mathrm{t}$} & \multirow{2}{*}{ Sig. } \\
\hline & $\mathrm{B}$ & Std. Error & & \\
\hline (Constant) & -3.696 & 0.724 & -5.102 & 0.000 \\
\hline Ln_Capital (CAR) & 0.621 & 0.084 & 7.365 & 0.000 \\
\hline Ln_Credit Risk (RAROC) & 0.121 & 0.027 & 4.546 & 0.000 \\
\hline Ln_Profitability $(\mathrm{ROA})^{\wedge} 2$ & 0.090 & 0.032 & 2.771 & 0.006 \\
\hline Ln_Liquidity (LDR) & 0.567 & 0.135 & 4.195 & 0.000 \\
\hline
\end{tabular}

Based on the data in Table 5, a multiple regression equation can be formulated as follows:

$$
\begin{aligned}
& \text { Means: } \\
& \mathbf{X}_{\mathbf{1}}=\text { CAR } \\
& \mathbf{X}_{\mathbf{2}}=\text { RAROC } \\
& \mathbf{X}_{\mathbf{3}}=\text { ROA } \\
& \mathbf{X}_{\mathbf{4}}=\text { LDR }
\end{aligned}
$$$$
Y=-3,696+0,621 X_{1}+0,121 X_{2}+0,090 X_{3}+0,567 X_{4}+e
$$

Based on the equation, some important things can be described as follows:

1) The constant was -3.696. This constant value means that Financial Distress will decrease with the assumption that the variables of capital, Ccredit risk, Profitability, and liquidity are in a constant state of zero.

2) The regression coefficient of the capital was 0.621 . The regression coefficient was positive, meaning that the capital variable has a positive impact on Financial Distress, or in other words, if capital increases by $1 \%$, it can be predicted that it will increase Financial Ddistress by $0.621 \%$, assuming other variables are in constant condition. (ceteris paribus).

3) The regression coefficient for the credit risk variable was 0.121 . When the regression coefficient is positive, meaning that the Credit risk has a positive effect on Financial Distress, or in other words if Credit risk increases 
by $1 \%$, it can be predicted that it will increase Financial Distress by $0.121 \%$, assuming other variables are in constant condition (ceteris paribus). .

4) The Profitability variable regression coefficient was 0.090 . When the regression coefficient is positive, meaning that the profitability variable has a positive effect on Financial Distress, or in other words if profitability increases by $1 \%$, it can be predicted that it will increase Financial Distress by $0.090 \%$, assuming other variables are in constant condition (ceteris paribus).

5) The Liquidity variable regression coefficient was 0.567 . When the regression coefficient is positive, meaning that the liquidity variable has a positive effect on Financial Distress, or in other words if liquidity increases by $1 \%$, it is predicted that it will increase Financial Distress by $0.567 \%$, assuming other variables are in constant condition (ceteris paribus).

\section{b. Coefficient of Determination}

The coefficient of determination shows how much variation in changes of the independent variable could explain variations in the dependent variable. The results of the determination test can be presented in Table 6 .

Table 6

Coefficient of Determination Test Result

\begin{tabular}{cccc}
\hline $\mathrm{R}$ & R Square & Adjusted R Square & Std. Error of the Estimate \\
\hline 0.735 & 0.540 & 0.527 & 0.23299 \\
\hline
\end{tabular}

Based on Table 6, the coefficient of determination (adjusted R2) was obtained 0.527. The adjusted R2 value showed that changes in Financial Ddistress were affected by variations of change in variables Capital, Credit risk, Profitability and Liquidity by $52.7 \%$, while the remaining $47.3 \%$ was affected by other variables which were not examined.

\section{Hypothesis Testing}

1) The effect of capital on Financial Distress

This study examined the effect of capital on Financial Ddistress. Based on the results of the regression analysis in Table 1, it was obtained that the $\mathbf{t}$ value of Capital was 7.365 with a significance value of 0.000 into a positive coefficient direction. The significance value of the capital was less than 0.05 , it could be concluded that partially the variable Capital had a positive effect on Financial Distress. This means that more default loans, led to higher the Financial Distress. The results of this study are consistent with Rahman et al. (2004), Nurazi and Evan (2005), Fukuda et al. (2006), Isanzu (2017) and Keffala (2018). This study proved that Capital had a positive effect on Financial Ddistress, so that the hypothesis statement in this study is accepted.

2) This study examined the effect of Credit risk on Financial Distress. According to the results of the regression analysis in Table 1, it was obtained that the $\mathbf{t}$ value of the credit risk variable was 4.546 with a significance value of 0.000 into a positive coefficient direction. The significance value of the credit risk variable was less than 0.05 , it could be concluded that partially the credit risk variable has a positive effect on Financial Distress. This means that the higher the credit risk led the higher the Financial Distress. The results of this study have also shown a consistent with the research of Brownbridge (1998), Rahman et al. (2004), Fukuda et al. (2007), Zaki et al. (2011), Kargi (2011), Keffala (2018), Gadzo et al. (2019), Onsongo et al. (2020), Ledhem and Mekidiche (2020), Asutay and Othman (2020), Kablay and Gumbo (2020). Results also found a positive effect of Credit risk on Financial Distress, so the hypothesis statement in thi study is accepted.

3) This study examined the effect of profitability on Financial Distress. According to the results of the regression analysis in Table 1, it was obtained that the $\mathbf{t}$ value of the profitability variable was 2.771 with a significance value of 0.006 into a positive coefficient direction. Due to the significance value of the profitability variable being less than 0.05 , it could be concluded that partially the profitability variable had a positive effect on Financial Distress. The results of this study are consistent with the results of research by Nurazi and Evan (2005), which stated that Earnings had a positive effect on Financial Distress conditions. There was a positive effect of Profitability on Financial Distress, so the hypothesis statement in this study is accepted.

4) Research examined the effect of liquidity on Financial Distress. According to the results of the regression analysis in Table 1, the $\mathbf{t}$ value of the Liquidity variable was 4.195 with a significance value of 0.000 into a positive coefficient direction. Due to the significance value of the liquidity variable being less than 0.05 , it could be concluded that partially the Liquidity variable had a positive effect on Financial Distress. The results of this study are consistent with research by Rahman et al. (2004), Keffala (2018) which state that liquidity factors have a positive effect on Financial Distress. There is a positive effect of Liquidity on Financial Distress, so the research hypothesis statement in this study is accepted. 


\section{Conclusions and implications}

\subsection{Conclusion}

1. Referred to the results of the study, it can be concluded that Capital, proxied by a Capital Adequacy Ratio, has a positive effect on Financial Distress.

2. Credit risk, proxied by risk adjusted return on capital, has a positive effect on Financial Distress.

3. Profitability, proxied by return on assets, has a positive effect on Financial Distress.

4. Liquidity, proxied by the loan to deposit ratio, has a positive effect on Financial Distress.

\subsection{Implications}

Based on the results the research analysis, statistically the variables of Capital, Credit risk, Profitability and Liquidity have a significant effect on Financial Distress. This means that variables are crucial factors to indicate Financial Distress condition. This is important valuable information for conventional commercial banks to well-controlled the variables, so that all indications potentially create Financial Distress conditions that can be managed properly and do not lead to bankruptcy.

\section{References}

Altman. (2002). Corporate Distress Prediction Model In A Turbulent Economic And Basel II Environment. School of Business, New York University.

Ashraf, S., GS Félix, E., \& Serrasqueiro, Z. (2019). Do traditional financial distress prediction models predict the early warning signs of financial distress?. Journal of Risk and Financial Management, 12(2), 55.

Asutay, M., \& Othman, J. (2020). Alternative measures for predicting financial distress in the case ofMalaysian Islamic banks: assessing the impact of global financial crisis. Journal of Islamic Accounting and Business Research, 11(9), 1759-0817.

Beaver, W. H., Correia, M., \& McNichols, M. (2011). Financial statement analysis and the prediction of financial distress. Now Publishers Inc.

Brownbridge. (1998). The Cause of Financial Distress in Local Bank in Africa and Implication for Prudential Policy. Macro Economic and Development Policies, GDS. Uniteed Natio Conference on Trade and Development (UNCTAD) Review, and Discussion Paper.UNCTAD/OSG/132.

Fitzpatrick, P. J. (1932). A comparison of the ratios of successful industrial enterprises with those of failed companies. Certified Public Accountant, 12, 598-605, 656-662, 727-731.

Fukuda, S. I., Kasuya, M., \& Nakajima, J. (2006). Deteriorating bank health and lending in Japan: evidence from unlisted companies under financial distress. Journal of the Asia Pacific Economy, 11(4), 482-501.

Gadzo, S. G., Kportorgbi, H. K., \& Gatsi, J. G. (2019). Credit risk and operational risk on financial performance of universal banks in Ghana: A partial least squared structural equation model (PLS SEM) approach. Cogent Economics \& Finance, $7(1), 1589406$.

Gutiérrez-López, C., \& Abad-González, J. (2020). Sustainability in the Banking Sector: A Predictive Model for the European Banking Union in the Aftermath of the Financial Crisis. Sustainability, 12(6), 2566.

Isanzu, J. S. (2017). The impact of credit risk on financial performance of Chinese banks. Journal of International Business Research and Marketing, 2(3).

Platt, H. D., \& Platt, M. B. (2002). Predicting corporate financial distress: reflections on choice-based sample bias. Journal of Economics and Finance, 26(2), 184-199.

Kargi. (2011). Credit Risk and Performance of Nigerian Banks. Development of Acounting Faculty of Administration Ahmadu Bello University, Zaria-Nigeria.

Keffala, M. R. (2018). Analyzing the effect of derivatives on the financial soundness of commercial banks in Italy: An approach based on the CAMELS framework. Review of Financial Economics, 36(3), 267-283.

Kablay, H., \& Gumbo, V. (2021). Bank Distress Prediction Model for Botswana. Asian Research Journal of Mathematics, 47-59.

Kurniasari, C., \& Ghozali, I. (2013). Analisis pengaruh rasio CAMEL dalam memprediksi financial distress perbankan Indonesia (Doctoral dissertation, Fakultas Ekonomika dan Bisnis).

Kuncoro, S., \& Agustina, L. (2017). Factors to Predict the Financial Distress Condition of the Banking Listed in The Indonesia Stock Exchange. Accounting Analysis Journal, 6(1), 39-47.

Ledhem, M. A., \& Mekidiche, M. (2020). Economic growth and financial performance of Islamic banks: a CAMELS approach. Islamic Economic Studies, 28(1), 47-62.

Lee, S. W., \& Mullineaux, D. J. (2004). Monitoring, financial distress, and the structure of commercial lending syndicates. Financial Management Association International, 33(3), 107-130.

Muriithi, J. G., Waweru, K. M., \& Muturi, W. M. (2016). Effect of credit risk on financial performance of commercial banks Kenya. Journal of Economic and Finance (IOSR-JEF), 7(4). 72-83. 
Nurazi, R., \& Evans, M. (2005). An Indonesian study of the use of CAMEL (S) ratios as predictors of bank failure. Journal of Economic \& Social Policy, 10(1), 143-167.

Onsongo, S. K., Muathe, S., \& Mwangi, L. W. (2020). Financial risk and financial performance: evidence and insights from commercial and services listed companies in Nairobi securities exchange, Kenya. International Journal of Financial Studies, 8(3), 51.

Rahman, S., Tan, L. H., Hew, O. L., \& Tan, Y. S. (2004). Identifying financial distress indicators of selected banks in Asia. Asian Economic Journal, 18(1), 45-57.

Sugiyono. (2017). Metode Penelitian Kuantitatif, Kualitatif, dan R\&D. Bandung : Alfabeta.

Vassalou, M., \& Xing, Y. (2004). Default risk in equity returns. The journal of finance, 59(2), 831-868.

Yurivin, N., \& Mawardi, W. (2018). Analisis Faktor-Faktor Yang Mempengaruhi Financial Distress Pada Perusahaan Perbankan Di Indonesia (Studi Pada Bank Umum Swasta Devisa Dan Non Devisa Periode 2012-2016) (Doctoral dissertation, Fakultas Ekonomika dan Bisnis).

Zaki, E., Bah, R., \& Rao, A. (2011). Assessing probabilities of financial distress of banks in UAE. International Journal of Managerial Finance, 7(3), 304-320.

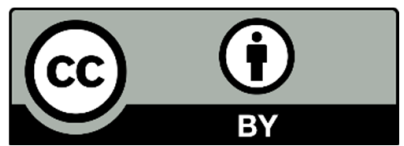

(C) 2022 by the authors; licensee Growing Science, Canada. This is an open access article distributed under the terms and conditions of the Creative Commons Attribution (CC-BY) license (http://creativecommons.org/licenses/by/4.0/). 